\title{
Marketing Extension Of Marketing Area (Distribution Channel) In Ketumbar Crackers (Kriuk Baren) Business In Curah Lele Village, Balung District, Jember District
}

\author{
Tri Palupi Robustin \\ STIE Widya Gama Lumajang \\ tripalupirobustin@gmail.com
}

\begin{tabular}{lll}
\hline Submission : & Review : & Publication : \\
$2^{\text {st }}$ January 2020 & $13^{\text {th }}$ January 2020 & $28^{\text {th }}$ February 2020 \\
\hline
\end{tabular}

\begin{abstract}
Abstrak
Distribution channels have an important role in the distribution of a product from producers to the end consumers in order to meet the wants and needs of consumers. This is one of the obstacles for UMKM in expanding distribution channels. Coriander Crackers (Baren's Kriuk) is a small and medium business that was established around the end of 2018 which is located in the village of Curah Lele Balung District Jember Regency. The problem faced by the home industry of coriander crackers barri 's kriuk is in the field of marketing especially the marketing area (distribution channel) which is less expanded, especially in the jember city area. Community service activities are expected to produce targets in accordance with partner expectations, namely: (1) Broader marketing area (distribution channels) so that products are better known to the wider community; (2) Better packaging innovation.
\end{abstract}

Keywords : Distribution Channel, Baren's Kriuk, Home Industy

\section{INTRODUCTION}

As Indonesians, our daily scenery and activities are inseparable from the various services and goods created by SMEs. Starting with morning activities when we are looking for breakfast porridge or pastry snacks sold by MSMEs, buying basic necessities at a warung near the house, to entrusting children to the nearest playgroup which also is MSMEs. In the current digital era, some even do not have a store and only market their products online, and do not yet have a business license. Business actors with these characteristics can be found around us be it relatives, neighbors, friends or ourselves. From the name UMKM does have an extension of Micro, Small and Medium Enterprises (MSME), but make no mistake this little one has a very large and crucial contribution to our economy at a macro level.

Distribution channels have an important role in the distribution of a product from producers to reach the end consumers in order to meet the desires and needs of consumers. Therefore, the company indirectly understands how to meet the desires and needs of consumers in the right time, place and number and think about choosing the right distribution channel. Understanding distribution channels is actually a group of interdependent organizations that help each other make products or services that are ready to be used or consumed by consumers or business users Kotler and Armstrong, (2008: 40).

Coriander Crackers (Baren's Kriuk) is a small and medium business that was established around the end of 2018 with the name of the owner Reni Hidayati with an address in the village of Curah Lele Balung District Jember Regency. Coriander crackers are 
produced using raw materials of flour, garlic, flavoring and coriander, once processing the dough around $5 \mathrm{~kg}$ and depending on orders from customers. The price of crackers per ball of large packaging is sold at Rp. 60,000, if there is a buyer or retailer then $1 \mathrm{~kg}$ is sold at a price of Rp. 13,000. Coriander crackers barri's crisps serve large and bulk purchases.

The production process requires 8 workers and must be supported by hot weather, otherwise crackers are not perfect. The employees at Baren's Kriuk are neighbors ie housewives who do not have work. Coriander crackers crackers are distributed outside the city including Surabaya and Central Java, and distribution within the city is only in the nearest area such as the Balung market and no broad distribution channels have been made.

This community service activity aims to help coriander cracker business owners to expand their marketing area with the aim of introducing products elsewhere. This activity also provides knowledge to business owners regarding the importance of expanding distribution channels that not only distribute products from producers to consumers but also have benefits to promote products to the wider community. The community service team also provided assistance with sealers to improve product packaging and stoves for the production process.

The problems faced by the coriander crackers barri's cracker home industry are: (a) The marketing sector especially the marketing area (distribution channel) which is less expanded, especially in the jember area of the city, (b) Product packaging (Packaging) that is still not good that is still using staples to cover the plastic (packaging).

Based on the problems faced by the home industry of coriander crackers (barri's kriuk) so partners need assistance for the expansion of marketing areas (distribution channels) so that products are better known to the wider community and assistance for packaging innovation (packaging) so that packaging is better. Expanding distribution or sales channels is one of the company's strategies to promote its products to be known by the public. In addition, the community service team provided assistance in the form of a sealer for a better and neater packaging process. One of the factors that influence consumer purchasing decisions is from good product packaging, so companies need to implement this strategy to differentiate products from competitors.

Community service activities are expected to produce targets in accordance with the expectations of community service partners, namely: (1) Broader marketing area (distribution channels), (2) Better packaging innovation.

\section{IMPLEMENTATION METHODS}

The steps of Implementation this service are as follows: (1) Location survey to see the condition of cracker business, (2) Interview with community service partners related to the history of the establishment of coriander crackers barri's crises and the problems encountered, (3) See the process of making coriander crackers, (4) Buy the help of production equipment and packaging processes, including stoves and sealers, (5) Help sell products in other regions, namely in Wirolegi Jember.

The method of implementation that will be carried out to resolve partner group problems consists of the following steps: (1) Providing assistance by buying several tools to speed up the production process, namely in the form of a stove and buying a sealer to help with more perfect packaging, (2) Help sell products (coriander crackers) in other regions, namely in the Wirolegi market in Jember Regency. It aims to promote crackers in other areas so that crackers are more widely known by the wider community. 


\section{RESULTS AND DISCUSSION}

The results of the implementation of community service activities are:

1. Business location survey so that information on the location of the business is established and the signature of the cooperation statement with the business partner is obtained.

2. Interview with the soy milk business owner, information about the history of the establishment of the business and business problems is obtained.

3. Getting knowledge and documentation of the process of making coriander crackers.

4. Buy stoves and sealers for good cracker production and packaging processes.

5. Help sell crackers in the Jember area, especially in the traditional wirolegi market.

Community service activities can produce outcomes in accordance with partner expectations, namely:

1. Coriander cracker marketing channels (distribution channels) are wider, and products will be more widely known by the public, because the other function of distribution channels is as a promotional tool;

2. Improved packaging innovation (packaging) is better, so that partners get knowledge related to product strategy through packaging.

\section{CONCLUSION}

Based on the results of the community service that has been carried out, a number of conclusions can be drawn as follows:

1. Coriander crackers barri's crises are small and medium businesses that have business constraints in the field of marketing and packaging.

2. Facilitating the expansion of marketing areas (distribution channels) and assisting in a good packaging process will assist in marketing activities, especially expanding market areas in other regions, especially in the Wirolegi Jember Traditional Market with the aim that products are widely known by the public and increase sales. This community service activity also provides stove and sealer assistance with the aim of speeding up the production process (steaming crackers) and improving packaging. In addition, the service team also provides counseling about the good packaging process so that it is expected to help the process of increasing sales, because good and quality packaging will affect the product image in consumers 'minds so that it will affect consumers' buying interest.

The role of MSMEs in the economy is quite large and in the current era of globalization, business people are competing to advance businesses, one of which is by expanding attractive market and packaging areas. One of the problems of MSMEs is the difficulty in distributing its products. Therefore, UMKM products especially coriander crackers barri's kriuk to pay more attention to the promotion of its products one of which through the expansion of distribution channels so that it is better known by the wider community. One strategy is to expand the marketing area by entrusting products to shops or to traditional markets, in addition to promotion, business owners should improve packaging so that they are more attractive for consumers to buy.

\section{REFERENCES}

Bernhart Farras. 2019. (https://www.cnbcindonesia.com/news/20190111134416-450214/umkm-kalah-saing-jokowi-beberkan-masalahnya). CNBC Indonesia. 
Kotler, P. Gary amstrong. 2008. Prinsip-Prinsip Pemasaran. Jilid I. Edisi Kesembilan. Jakarta: Penerbit Erlangga. 